\title{
Rate Analysis of Two Photovoltaic Systems in San Diego
}

Technical Report NREL/TP-6A2-43537 July 2009

Elizabeth Doris, Sean Ong, and Otto Van Geet

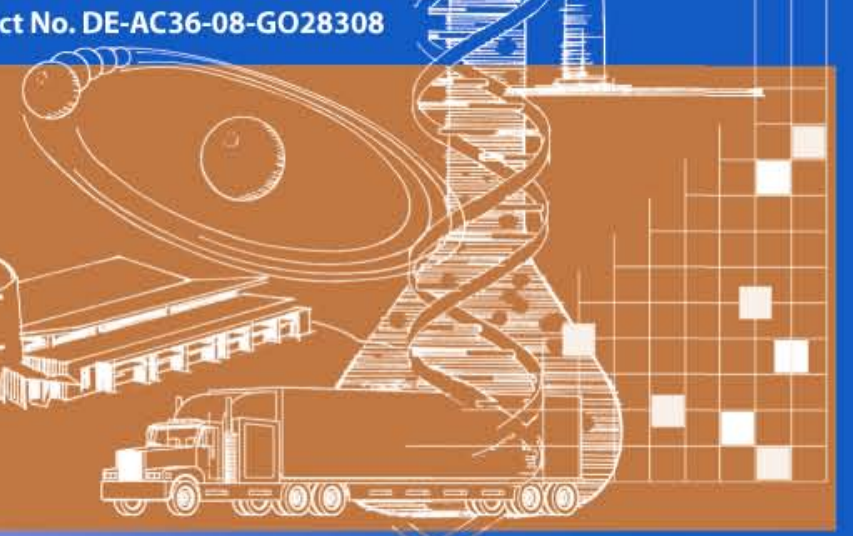




\section{Rate Analysis of Two Photovoltaic Systems in San Diego}

\section{Technical Report NREL/TP-6A2-43537 July 2009}

Elizabeth Doris, Sean Ong, and Otto Van Geet

Prepared under Task No. PVC7.92LA

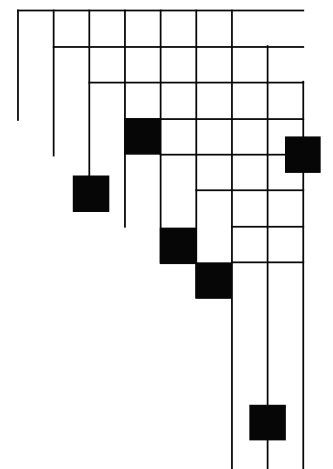




\section{NOTICE}

This report was prepared as an account of work sponsored by an agency of the United States government. Neither the United States government nor any agency thereof, nor any of their employees, makes any warranty, express or implied, or assumes any legal liability or responsibility for the accuracy, completeness, or usefulness of any information, apparatus, product, or process disclosed, or represents that its use would not infringe privately owned rights. Reference herein to any specific commercial product, process, or service by trade name, trademark, manufacturer, or otherwise does not necessarily constitute or imply its endorsement, recommendation, or favoring by the United States government or any agency thereof. The views and opinions of authors expressed herein do not necessarily state or reflect those of the United States government or any agency thereof.

Available electronically at http://www.osti.gov/bridge

Available for a processing fee to U.S. Department of Energy and its contractors, in paper, from:

U.S. Department of Energy

Office of Scientific and Technical Information

P.O. Box 62

Oak Ridge, TN 37831-0062

phone: 865.576 .8401

fax: 865.576 .5728

email: mailto:reports@adonis.osti.gov

Available for sale to the public, in paper, from:

U.S. Department of Commerce

National Technical Information Service

5285 Port Royal Road

Springfield, VA 22161

phone: 800.553 .6847

fax: 703.605.6900

email: orders@ntis.fedworld.gov

online ordering: http://www.ntis.gov/ordering.htm 


\section{Acknowledgments}

This work is made possible by the U.S. Department of Energy Solar Energy Technology Program, through the San Diego Solar America Cities Grant. The authors thank Tom Blair and Linda Pratt of the City of San Diego, as well as Andrew McCallister of the California Center for Sustainable Energy, for their assistance in the development and reviews of this work. The authors also thank Michelle Kubik for her editing and production of the report. Any remaining errors, of course, remain the responsibilities of the authors. 


\section{Table of Contents}

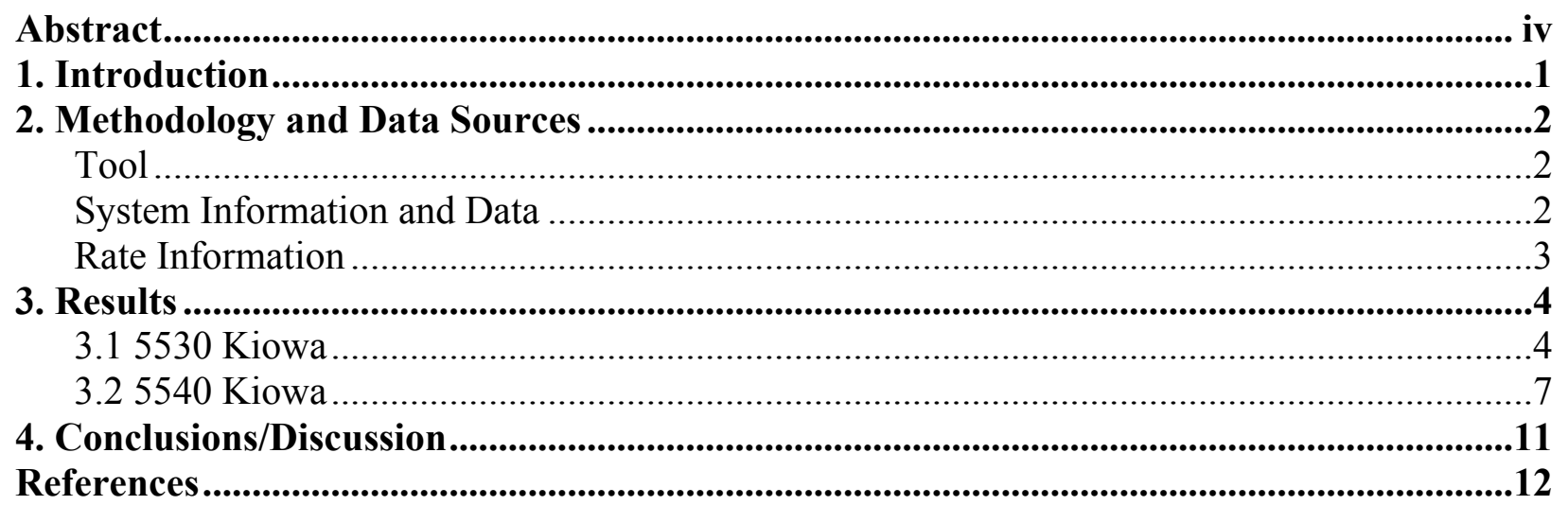

\section{List of Figures}

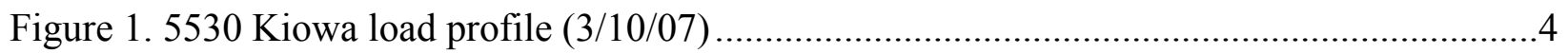

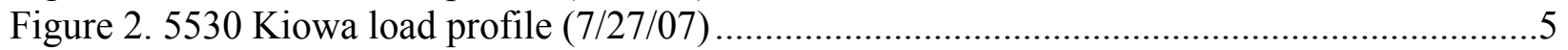

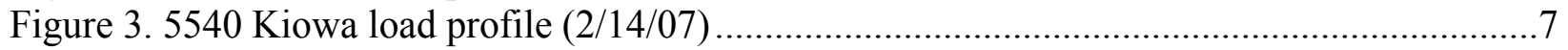

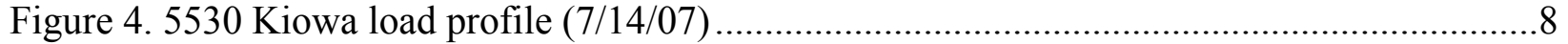

Figure 5. Rate and PV production coincidence (PAT1D) - summer .............................................

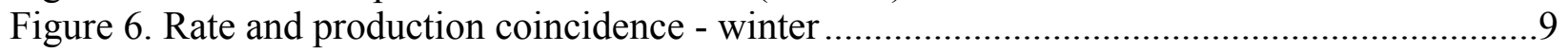

\section{List of Tables}

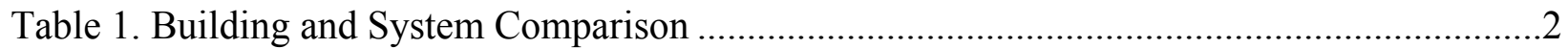

Table 2. Rate Structure Scenarios Used in Analysis...................................................................

Table 3. 5530 Kowa Electric Bill Comparison Table ....................................................................

Table 4. 2007 PV System Savings over Case with No PV System ..............................................6

Table 5. Summary of PV System Savings over PAT-1D Rate …………………...........................6

Table 6. 5540 Kowa Electric Bill Comparison Table ………......................................................9

Table 7. 2007 PV System Savings over Case with No PV System ............................................10

Table 8. Summary of PV System Savings over PAT-1D Rate .....................................................10 


\section{Abstract}

Analysts have found increasing evidence that rate structure has impacts on the economics of solar systems (e.g., Wiser et al. 2007, Borenstein 2007). This paper uses 2007 15-minute interval photovoltaic (PV) system and load data from two San Diego City water treatment facilities to illustrate impacts of different rate designs. The comparison is based on rates available in San Diego at the time of data collection and include proportionately small to large demand charges (relative to volumetric consumption), and varying on- and off- peak times.

Findings are twofold for these large commercial systems: 1) transferring costs into demand charges does not result in savings and 2) changes in peak times do not result in a major cost difference during the course of a year. While lessons learned and discussions on rate components are based on the findings, the applicability is limited to buildings with similar systems, environments, rate options, and loads. 


\section{Introduction}

Solar photovoltaic (PV) systems are touted as beneficial under certain circumstances because of their long-term economic and external benefits (Smeloff 2005). Long-term system economics depend on geography, available incentives, maintenance practices, competing energy costs, the ability and value of exporting the energy, the rate structure under which the system is operating, and the ratio of system capacity to building load (Wiser et al. 2007). While methodologies are developed for understanding many of the factors affecting PV systems, the impact of rate structure varies based on system size, building load, and capacity relative to building load, resulting in a complicated relationship that is difficult to generalize.

The impact of rates on PV systems is increasingly studied as more site-specific data becomes available. While generalizations about rates are still challenging due to the high levels of rate design and system configuration variation, it is likely that the economics of PV that are greatly assisted by rates that reflect the actual value to the utility system and the customer. This paper adds to the body of literature by evaluating different rate structures on two co-located, netmetering eligible, ${ }^{1} 0.5 \mathrm{MW}$ scale, solar PV installations serving two separate buildings, both with mid-day peaks, in San Diego, California.

As of January 2009, the San Diego area has $50 \mathrm{MW}$ of installed PV, all connected to the local utility grid of San Diego Gas and Electric (SDG\&E). The City of San Diego has been a regional leader in PV implementation, with 1.4 MW of PV currently installed on city facilities. In San Diego, there is increasing emphasis on solar power as an important source of in-region generation. It's also recognized for its potential to improve reliability, hedge future rate increases, decrease regional carbon emissions, and diversify the resource base. The city has invested in multiple solar PV systems and measurement equipment to evaluate system effectiveness for both cost and energy reliability. To determine the viability of future investments, it is important to understand the impacts of those PV systems on the city's cost of energy, as well as greater impacts on the grid.

A detailed understanding of each rate, combined with load data from particular facilities, provides a solid basis for analysis that can inform energy-management decision making. The wealth of data collected on the San Diego systems will help analyze the relative impact of different rates on the specific solar PV systems and their associated electricity loads, which is vital information for city officials going forward.

This paper uses the first year of 15-minute interval load and production data from the systems to identify and determine how rates impact the cost-effectiveness of the system. The comparison is based on rates available in San Diego at the time of data collection and include proportionately small to large demand charges (relative to volumetric consumption), and varying on- and offpeak times.

\footnotetext{
${ }^{1}$ Under energy net-metering, the electric customer avoids consumption from the grid with each kilowatt-hour $(\mathrm{kWh})$ produced on-site, thus is implicitly credited with the retail value of that energy. Momentary (net) overproduction is also credited at the retail energy rate.
} 


\section{Methodology and Data Sources}

\section{Tool}

The Microsoft Excel-based tool used in this analysis is specifically designed to evaluate the impact of different rates on photovoltaic systems for any location throughout the United States. By combining the ability to analyze both energy and demand charges, the tool can be used to assess the financial benefit of stand-alone PV systems and PV systems integrated with a specific building or load. The accuracy of the tool, which is developed and housed at the National Renewable Energy Laboratory (NREL), is verified by comparing its data with actual utility bill data from the period of data collection.

The tool requires 15-minute data on building load and system production, as well as energy rate and demand charge information from a utility rate book. The tool precisely aligns the 15-minute load data with the 15-minute PV production to determine the reduction in demand for each 15minute segment. The tool then matches each 15 -minute segment to the electricity rate that is applicable during that time, which is used to determine the energy and demand charges. The tool summarizes the energy, demand, and cost savings for the various time segments, which allows analysts to identify the beneficial components in each rate structure related to the PV system.

\section{System Information and Data}

The systems tested here are two independent but co-located systems, which are owned and operated by Sun Edison under a power purchase agreement (PPA) with the City of San Diego. Both systems have PV panels mounted on open racks sloped 15 degrees. The facilities and the systems, identified by their addresses, have the following characteristics:

- 5530 Kiowa: a $495 \mathrm{~kW}$ alternating current (AC) system atop water treatment reservoirs that provides power for the water-testing lab building and pumping station. This system faces 45 degrees west of south.

- 5540 Kiowa: a $450 \mathrm{~kW}$ AC system also atop water treatment reservoirs that provides power for a drinking water pumping and pressurization system. This system faces south.

The system data are provided by the City of San Diego, based on a metering system installed at the site. Table 1 summarizes the differences between the building loads and systems.

Table 1. Building and System Comparison

\begin{tabular}{|c|c|c|}
\hline \multirow{2}{*}{ Building Type } & \multicolumn{2}{|c|}{ Address } \\
\hline & 5530 Kiowa & 5540 Kiowa \\
\hline Load Type & \multicolumn{2}{|c|}{ Single mid-day peak } \\
\hline $\begin{array}{l}\text { Average 15-minute interval } \\
\text { electricity use }\end{array}$ & $40-60 \mathrm{kWh}$ & 80-100 kWh \\
\hline PV System Size & $495 \mathrm{~kW} \mathrm{AC}$ & $450 \mathrm{~kW} \mathrm{AC}$ \\
\hline
\end{tabular}




\section{Rate Information}

San Diego has multiple rates to choose from, which is a major benefit in the analysis. In 2007, SDG\&E offered large users the opportunity to choose different peak and semi-peak times. These rates, called the PA-T-1A through PA-T-1D, allow for a detailed analysis of differences in peak times for real systems.

The nine rate structures used in the analysis (Table 1) are publicly available commercial rates for SDG\&E. During the data year, SDG\&E piloted several rate structures (PA-T-1A through D) that had common electricity and demand charges, but different peak, mid-peak (sometimes called "shoulder"), and off-peak times. The stated purpose of those rates was to allow consumers to optimize their energy costs based on highest periods of use. Both test systems in this analysis used rate PA-T-1-D in 2007. The energy charge rates for all of these time-of-use (TOU) options are the same:

- On-peak: summer $\$ 0.113 / \mathrm{kWh}$, winter $\$ 0.111 / \mathrm{kWh}$

- Semi-peak: summer $\$ 0.095 / \mathrm{kWh}$, winter $\$ 0.102 / \mathrm{kWh}$.

- Off-peak: $\$ 0.077$

In addition to the PAT-1 rates, the analysis applies other available rate structures to the data to determine impact of those rates on the economics of the solar installations. Some of these rates were available during the time period for the data collection (2007), but not all were applicable to these systems due to PV system size or building load requirements. Nonapplicable rates include AL-TOU, A6-TOU, A, and DWR. The final rate in Table 2, DG-R, became available after collecting the testing data. The DG-R rate was analyzed to approximate the impacts of reducing volumetric charges and increasing non-by-passable demand charges.

Table 2. Rate Structure Scenarios Used in Analysis (timing is for both electricity and demand charges)

\begin{tabular}{|c|c|c|c|c|c|c|c|}
\hline \multirow[b]{2}{*}{ Rate } & \multirow[b]{2}{*}{ Season } & \multicolumn{2}{|c|}{ On-Peak } & \multicolumn{2}{|c|}{ Semi-Peak 1} & \multicolumn{2}{|c|}{ Semi-Peak 2} \\
\hline & & Start & End & Start & End & Start & End \\
\hline \multirow[t]{2}{*}{ PAT1B } & Summer & 12:00 PM & 3:00 PM & 6:00 AM & 12:00 PM & 3:00 PM & 10:00 PM \\
\hline & Winter & 5:00 PM & 8:00 PM & 6:00 AM & 5:00 PM & 8:00 PM & 10:00 PM \\
\hline \multirow[t]{2}{*}{ PAT1C } & Summer & 12:00 PM & 4:00 PM & 6:00 AM & 12:00 PM & 4:00 PM & 10:00 PM \\
\hline & Winter & 5:00 PM & 8:00 PM & 6:00 AM & 5:00 PM & 8:00 PM & 10:00 PM \\
\hline \multirow[t]{2}{*}{ PAT1D } & Summer & 1:00 PM & 3:00 PM & 6:00 AM & 1:00 PM & 3:00 PM & 10:00 PM \\
\hline & Winter & 5:00 PM & 8:00 PM & 6:00 AM & 5:00 PM & 8:00 PM & 10:00 PM \\
\hline \multirow[t]{2}{*}{ PAT1E } & Summer & 1:00 PM & 4:00 PM & 6:00 AM & 1:00 PM & 4:00 PM & 10:00 PM \\
\hline & Winter & 5:00 PM & 8:00 PM & 6:00 AM & 5:00 PM & 8:00 PM & 10:00 PM \\
\hline \multirow{2}{*}{$\begin{array}{l}\text { AL- } \\
\text { TOU }\end{array}$} & Summer & 11:00 AM & 6:00 PM & 6:00 AM & 11:00 AM & 6:00 PM & 10:00 PM \\
\hline & Winter & 5:00 PM & 8:00 PM & 6:00 AM & 5:00 PM & 8:00 PM & 10:00 PM \\
\hline \multirow{2}{*}{$\begin{array}{l}\text { A6- } \\
\text { TOU }\end{array}$} & Summer & 11:00 AM & 6:00 PM & 6:00 AM & 11:00 AM & 6:00 PM & 10:00 PM \\
\hline & Winter & 5:00 PM & 8:00 PM & 6:00 AM & 5:00 PM & 8:00 PM & 10:00 PM \\
\hline \multirow[b]{2}{*}{ A } & Summer & \multirow{2}{*}{\multicolumn{6}{|c|}{ Flat Rate }} \\
\hline & Winter & & & & & & \\
\hline \multirow[t]{2}{*}{ DWR } & Summer & \\
\hline & Winter & \multicolumn{6}{|c|}{ Flat Rate } \\
\hline \multirow{2}{*}{$\begin{array}{l}\text { Proxy } \\
\text { DGR }\end{array}$} & Summer & 11:00 AM & 6:00 PM & 6:00 AM & 11:00 AM & 6:00 PM & 10:00 PM \\
\hline & Winter & 5:00 PM & 8:00 PM & 6:00 AM & 5:00 PM & 8:00 PM & 10:00 PM \\
\hline
\end{tabular}




\section{Results}

\subsection{Kiowa}

Figures 1 and 2 present typical summer and winter building load curves overlaid with solar installation production data for 5530 Kiowa. The building load is a typical mid-day single peak, and PV production has a nearly peak that nearly coincides with peak demand. During the summer, the peak production of the system is generally matched to and greater than the building load peak.

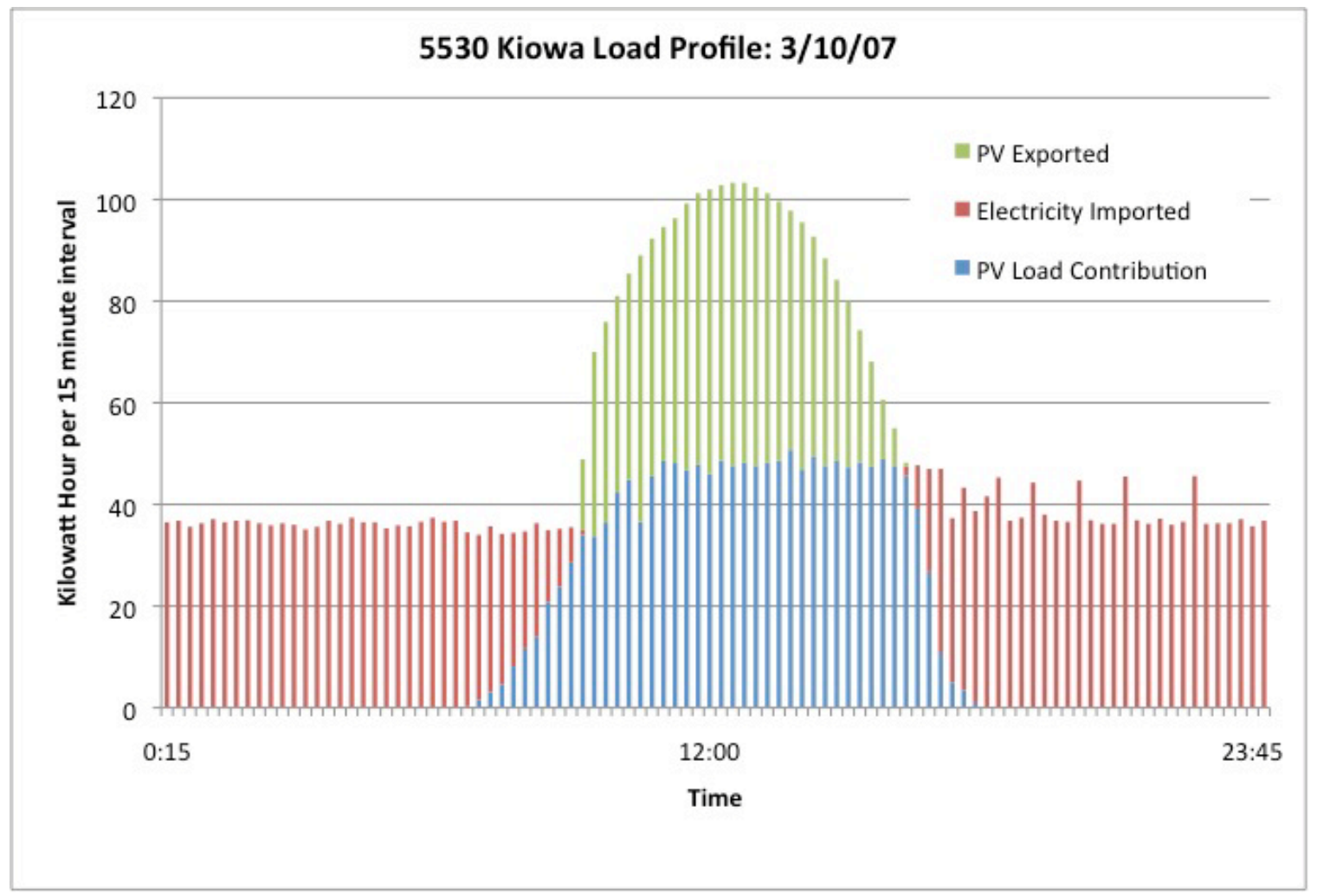

Figure 1. 5530 Kiowa load profile (3/10/07) 


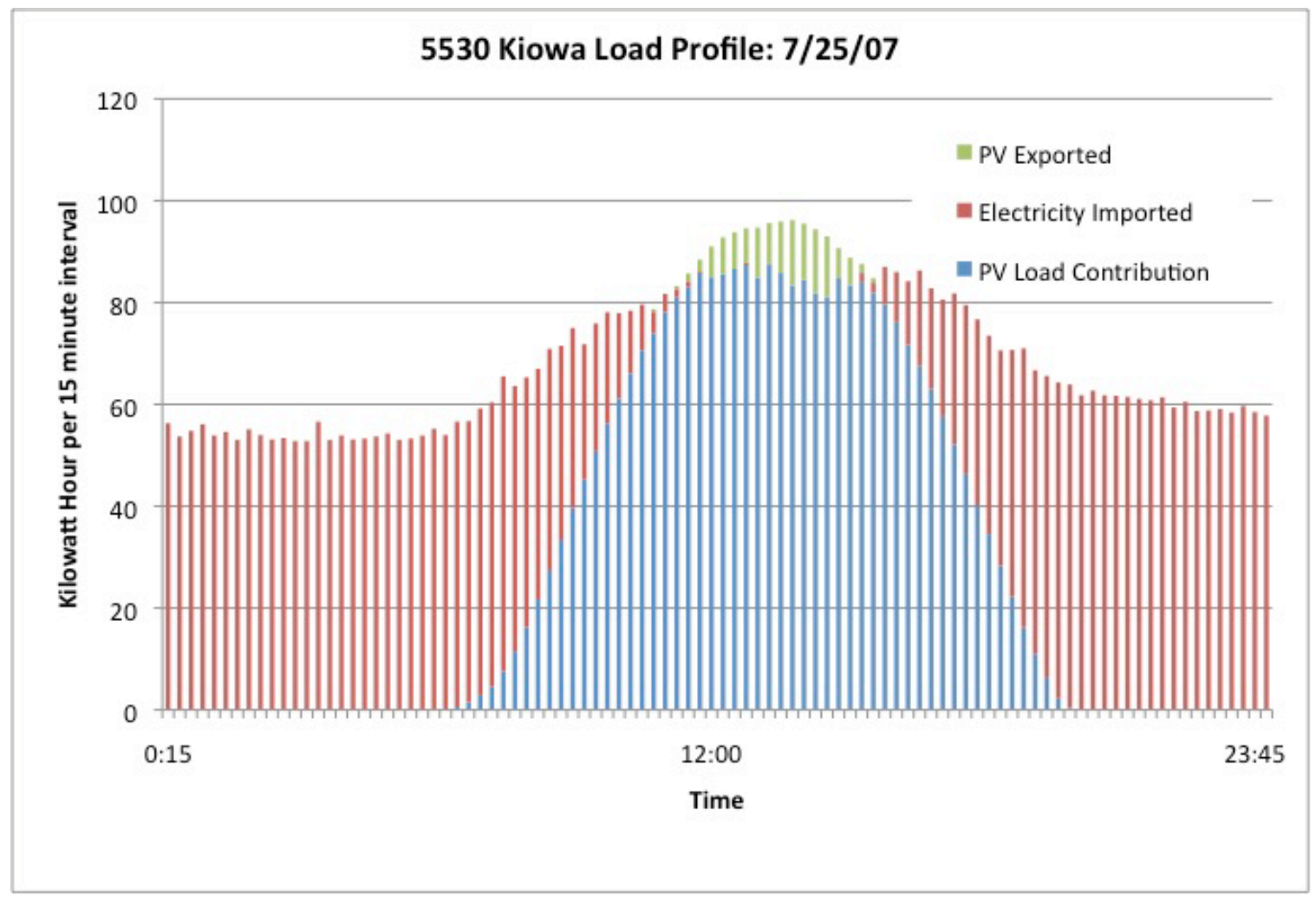

Figure 2. 5530 Kiowa load profile (7/27/07)

Table 3 summarizes the rate-impact results, which show that the rate that the system was functioning on, PA-T-1D \& -1E, was the most cost-effective of the available rates at the time of data collection (PA-T-1C-F), for a total cost of about $\$ 117,000$.

Table 3. 5530 Kiowa Electric Bill Comparison Table (annual)

\begin{tabular}{|l|r|r|r|}
\hline Rate Structure & Demand Charges & Electricity Charges & Total Bill Charges \\
\hline PA-T-1 C & $\$ 37,975$ & $\$ 80,165$ & $\$ 118,140$ \\
\hline PA-T-1 D & $\$ 36,947$ & $\$ 80,165$ & $\$ 117,112$ \\
\hline PA-T-1 E & $\$ 36,884$ & $\$ 80,165$ & $\$ 117,049$ \\
\hline PA-T-1 F & $\$ 39,866$ & $\$ 80,165$ & $\$ 120,031$ \\
\hline AL-TOU & $\$ 52,087$ & $\$ 81,743$ & $\$ 133,830$ \\
\hline A6-TOU & $\$ 57,451$ & $\$ 78,604$ & $\$ 136,055$ \\
\hline A & $\$ 0$ & $\$ 96,478$ & $\$ 96,478$ \\
\hline DWR & $\$ 0$ & $\$ 93,926$ & $\$ 93,926$ \\
\hline DGR (proxy) & $\$ 16,160$ & $\$ 116,264$ & $\$ 132,424$ \\
\hline
\end{tabular}

Assuming the same rate structure with and without a PV system, the PV system results in a savings of between $43 \%$ and $51 \%$ of total annual electricity billed costs (Table 4). Table 5, however, presents a more realistic scenario for estimating the overall value of the system because the case with no PV system is associated with a single rate - in this case, the PA-T-1D rate.

Tables 4 and 5 illustrate that rates with lower demand charges result in higher bill savings for the PV installation relative to no system. It is clear that the rate approximating DGR (proxy rate) 
provides the largest savings for a solar installation when measured relative to the same rate without a solar installation. However, the 2007 applicable rates with the largest cost savings relative to no system are the PAT-1-C-E rates. If the building qualified for the DWR rate, that would have the largest positive economic impact on the system over a basic time-of-use rate such as the PAT1D in the absence of a system. The result is that the time-of-use rates with lower demand charges provide more savings for this solar installation than those with higher demand charges.

Table 4. 2007 PV System Savings (\$) over Case with No PV System (same rate)

\begin{tabular}{|l|r|}
\hline \multicolumn{1}{|c|}{ Rate Structure } & Total \\
\hline PA-T-1 C & $46 \%$ \\
\hline PA-T-1 D & $46 \%$ \\
\hline PA-T-1 E & $46 \%$ \\
\hline PA-T-1 F & $45 \%$ \\
\hline AL-TOU & $44 \%$ \\
\hline A6-TOU & $43 \%$ \\
\hline A & $48 \%$ \\
\hline DWR & $47 \%$ \\
\hline DGR (proxy) & $51 \%$ \\
\hline
\end{tabular}

Table 5. Summary of PV System Savings over PAT-1D Rate

\begin{tabular}{|c|c|c|c|c|}
\hline \multirow[b]{2}{*}{ Rate Structure } & \multicolumn{2}{|c|}{ Annual Building Energy Costs } & \multirow{2}{*}{$\begin{array}{l}\text { Savings over } \\
\text { no system at } \\
\text { PAT-1-D } \\
\text { Rate }\end{array}$} & \multirow{2}{*}{$\begin{array}{l}\text { Savings over } \\
\text { no system at } \\
\text { PAT-1-D Rate }\end{array}$} \\
\hline & No PV (PAT-1-D) & With PV System & & \\
\hline PA-T-1 C & \multirow{9}{*}{$\$ 218,421$} & $\$ 118,140$ & $\$ 100,281$ & $46 \%$ \\
\hline PA-T-1 D & & $\$ 117,112$ & $\$ 101,309$ & $46 \%$ \\
\hline PA-T-1 E & & $\$ 117,049$ & $\$ 101,372$ & $46 \%$ \\
\hline PA-T-1 F & & $\$ 120,031$ & $\$ 98,390$ & $45 \%$ \\
\hline AL-TOU & & $\$ 133,830$ & $\$ 84,591$ & $39 \%$ \\
\hline A6-TOU & & $\$ 136,055$ & $\$ 82,366$ & $38 \%$ \\
\hline $\mathrm{A}$ & & $\$ 96,478$ & $\$ 121,943$ & $56 \%$ \\
\hline DWR & & $\$ 93,926$ & $\$ 124,495$ & $57 \%$ \\
\hline DGR (proxy) & & $\$ 132,424$ & $\$ 85,997$ & $39 \%$ \\
\hline
\end{tabular}

This building load is primarily coincident with peak production, resulting in high levels of demand savings over the course of 2007. For the actual rate option used by the system in 2007 (PA-T-1D), the demand savings resulted in $\$ 101,309$ in savings, or a $46 \%$ total bill reduction for the facility. If the demand-charge reductions remain consistent over the life of the system, the demand savings radically increase the system economics. However, demand is measured every 15 minutes, and charged for the highest point in a month. Therefore, if that peak moment is hit coincident with a low production moment (e.g., a cloud passing over), savings will vary year to year, and could be offset by a few low production days, especially given the stability of the building load. 


\subsection{Kiowa}

Figures 3 and 4 represent typical summer and winter building loads for this site. The load at this site has relatively higher average daily load, making the peak relatively smaller than the one at 5530 Kiowa. Figure 5 illustrates the coincidence of the peak periods in the time-of-use rate structure offered to 5540 Kiowa and the solar PV production. This coincidence is critical to the system economics and involves coordinated rate and system design.

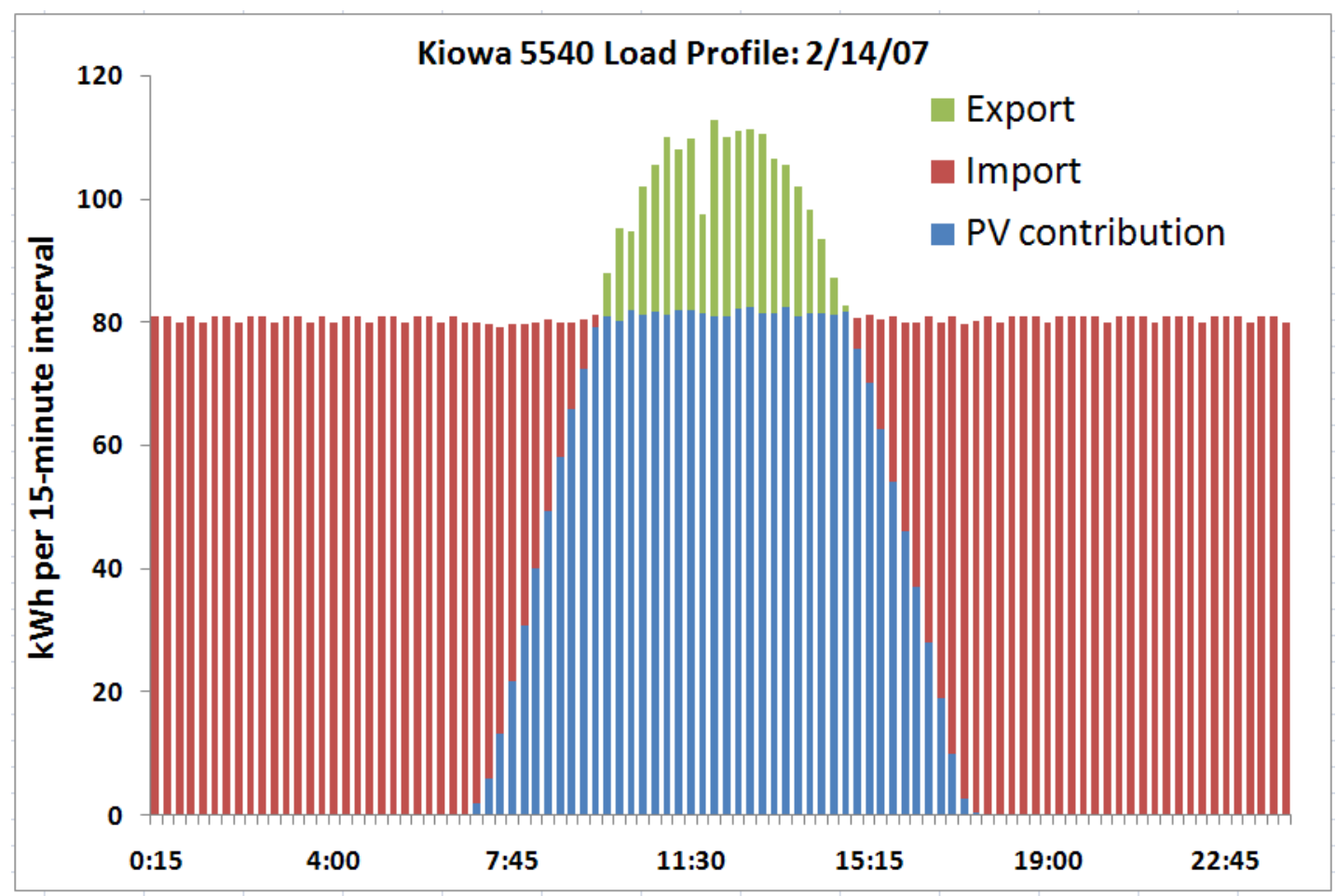

Figure 3. 5540 Kiowa load profile (2/14/07) 


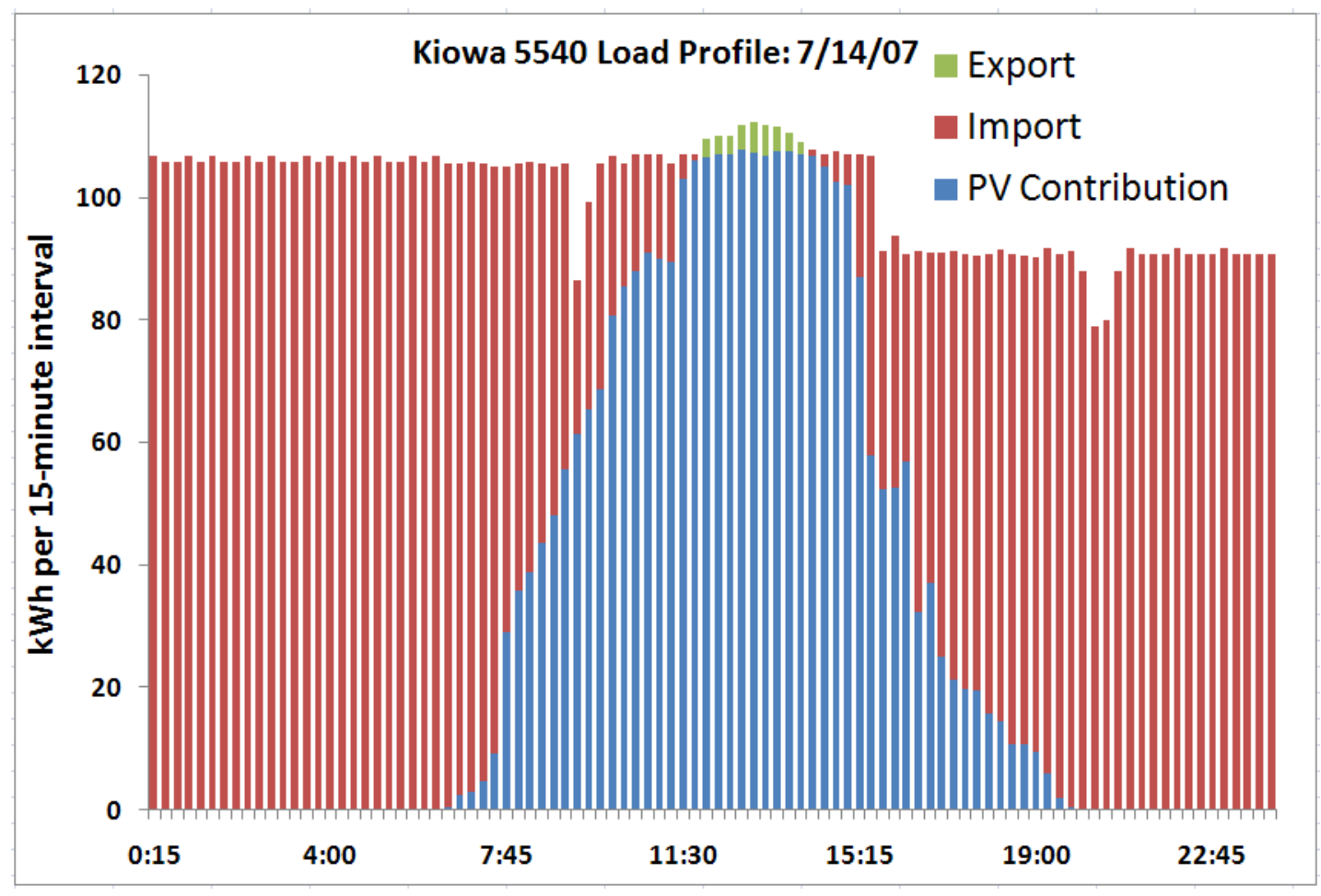

Figure 4. 5540 Kiowa load profile (7/14/07)

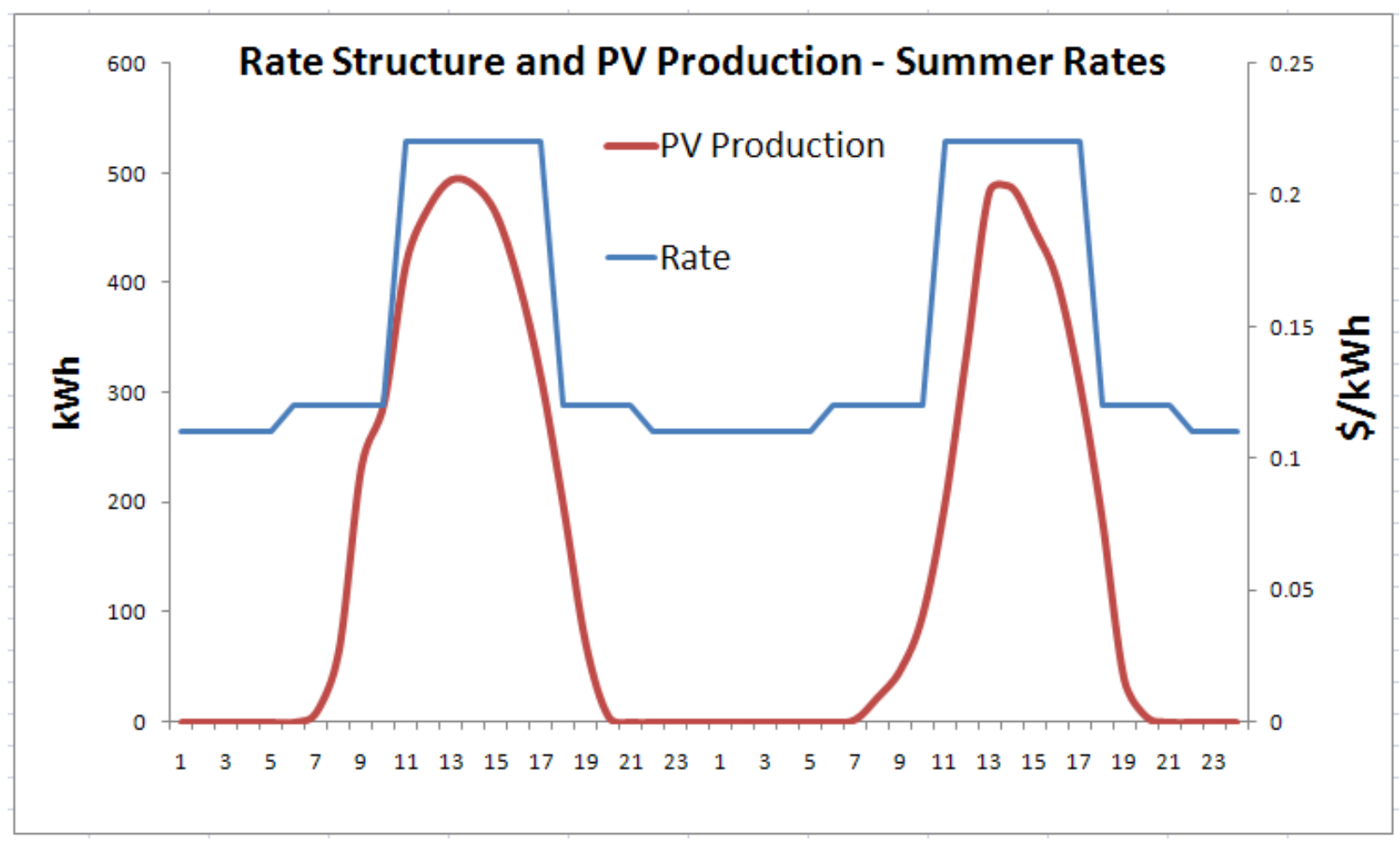

Figure 5. Rate and PV production coincidence (PAT1D) - summer 


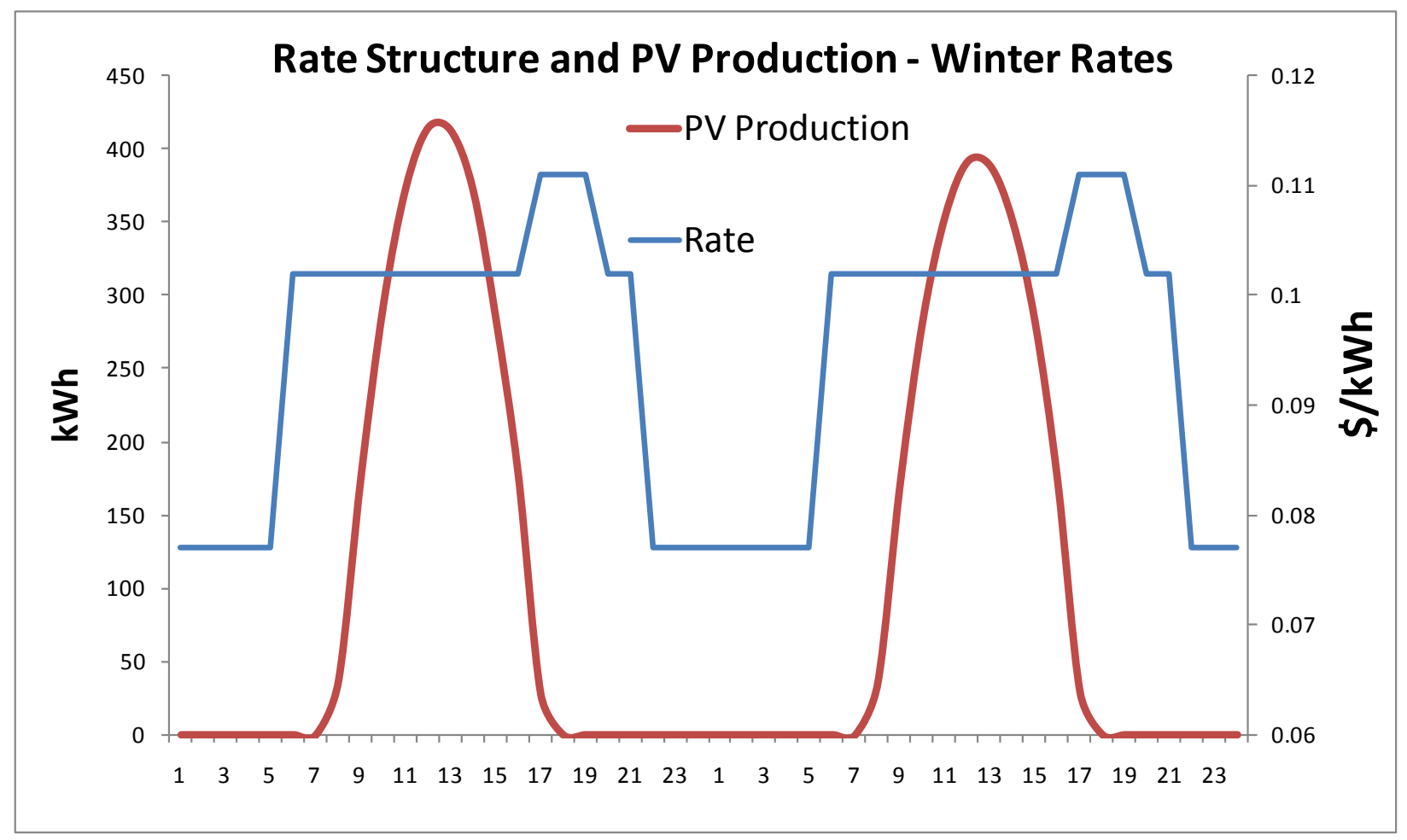

Figure 6. Rate and production coincidence - winter

Table 6 summarizes the rate-impact results, which show that the rate that the system was functioning on, PA-T-1D was the most cost-effective of the available rates at the time of data collection (PA-T-1C-F), for a total cost of about $\$ 46,576$.

Table 6. 5540 Kiowa Electric Bill Comparison Table (annual)

\begin{tabular}{|l|r|r|r|}
\hline Rate Structure & Demand Charges & Electricity Charges & Total Bill Charges \\
\hline PA-T-1 C & $\$ 45,596$ & $\$ 3,359$ & $\$ 48,956$ \\
\hline PA-T-1 D & $\$ 43,216$ & $\$ 3,359$ & $\$ 46,576$ \\
\hline PA-T-1 E & $\$ 44,606$ & $\$ 3,359$ & $\$ 47,966$ \\
\hline PA-T-1 F & $\$ 51,686$ & $\$ 3,359$ & $\$ 55,046$ \\
\hline AL-TOU & $\$ 60,268$ & $\$ 2,916$ & $\$ 63,184$ \\
\hline A6-TOU & $\$ 65,822$ & $\$ 3,218$ & $\$ 69,040$ \\
\hline A & $\$ 0$ & $\$ 16,343$ & $\$ 16,343$ \\
\hline DWR & $\$ 0$ & $\$ 12,645$ & $\$ 12,645$ \\
\hline DGR (proxy) & $\$ 19,163$ & $-\$ 325$ & $\$ 18,838$ \\
\hline
\end{tabular}

Assuming the same rate structure with and without a PV system, the PV system results in a savings of between $63 \%$ and $89 \%$ of total annual electricity billed costs (Table 7). Table 8, however, presents a more realistic scenario for estimating the overall value of the system because the case with no PV system is associated with a single rate - in this case, the PA-T-1D rate.

Tables 7 and 8 illustrate that rates with lower demand charges result in higher bill savings for this PV installation relative to no system. Similar to the system at 5530 Kiowa, the rate 
approximating DGR (proxy rate) provides the largest savings for a solar installation relative to the same rate without a solar installation. However, when measuring savings between the rates, assuming a PV system, the PAT-1-C-E rates offer the largest savings. The result for this system as well, then, is that the time-of-use rates with lower demand charges provide more savings for this solar installation than those with higher demand charges.

Table 7. 2007 PV System Savings (\$) over Case with No PV System (same rate)

\begin{tabular}{|l|r|}
\hline \multicolumn{1}{|c|}{ Rate Structure } & Total \\
\hline PA-T-1 C & $70 \%$ \\
\hline PA-T-1 D & $72 \%$ \\
\hline PA-T-1 E & $71 \%$ \\
\hline PA-T-1 F & $66 \%$ \\
\hline AL-TOU & $66 \%$ \\
\hline A6-TOU & $63 \%$ \\
\hline A & $86 \%$ \\
\hline DWR & $88 \%$ \\
\hline DGR (proxy) & $89 \%$ \\
\hline
\end{tabular}

Table 8. Summary of PV System Savings over PAT-1D Rate

\begin{tabular}{|c|c|c|c|c|}
\hline \multirow[b]{2}{*}{ Rate Structure } & \multicolumn{2}{|c|}{ Annual Building Energy Costs } & \multirow{2}{*}{$\begin{array}{l}\text { Savings over } \\
\text { no system at } \\
\text { PAT-1-D } \\
\text { Rate }\end{array}$} & \multirow{2}{*}{$\begin{array}{l}\% \text { savings over } \\
\text { no system at } \\
\text { PAT-1-D Rate }\end{array}$} \\
\hline & No PV (PAT-1-D) & With PV System & & \\
\hline PA-T-1 C & \multirow{9}{*}{$\$ 165,732$} & $\$ 48,956$ & $\$ 116,776$ & $70 \%$ \\
\hline PA-T-1 D & & $\$ 46,576$ & $\$ 119,156$ & $72 \%$ \\
\hline PA-T-1 E & & $\$ 47,966$ & $\$ 117,766$ & $71 \%$ \\
\hline PA-T-1 F & & $\$ 55,046$ & $\$ 110,686$ & $67 \%$ \\
\hline AL-TOU & & $\$ 63,184$ & $\$ 102,548$ & $62 \%$ \\
\hline A6-TOU & & $\$ 69,040$ & $\$ 96,692$ & $58 \%$ \\
\hline $\mathrm{A}$ & & $\$ 16,343$ & $\$ 149,389$ & $90 \%$ \\
\hline DWR & & $\$ 12,645$ & $\$ 153,087$ & $92 \%$ \\
\hline DGR (proxy) & & $\$ 18,838$ & $\$ 146,894$ & $89 \%$ \\
\hline
\end{tabular}




\section{Conclusions/Discussion}

This report provides analysis of different utility rates on two PV systems in San Diego, California. It provides a study of two relatively same-sized, co-located systems on buildings with different load profiles. Rates available during the time of system measurement, as well as a proxy rate illustrating increased demand charges relative to volumetric charges, are evaluated. Findings indicate that changes in peak timing did not have a major effect on the economics of the system over the course of a year, and that increased demand charges relative to volumetric charges do not increase the economic value of these two solar systems.

The results support existing literature on the importance of relative sizing of PV systems and the load being served (Wiser et al. 2007). The system installed at 5530 Kiowa is oversized relative to peak load, and 5540 Kiowa is sized to meet peak demand. As a result, the 5540 Kiowa system, under all rates tested, offsets more of the energy costs of the building.

Regarding the most beneficial rate structures, those that exhibit the greatest benefits all have lower demand charges and time-of-use rates, which peak during peaks in PV production. Typically, a utility will provide a TOU rate that has a high peak charge and a low off-peak charge. Such rate structures encourage customers to shift their electricity use to off-peak times, making it a good demand-side management tool for the utility. Solar PV system owners benefit from TOU rates because of the low off-peak charges and because a PV system typically reduces their electricity imports during peak hours. A rate structure that peaks during the hours of PV production will have the greatest benefit to the system owner.

For a TOU rate to be beneficial, the PV system needs to be designed to provide the bulk of the electricity load for the building. If not, the high-price electricity purchased on-peak will offset the savings provided by the system. It is the combination of low off-peak rates and low energy use during peak hours (due to the PV system's contribution) that results in the savings. However, even if the system is undersized relative to building load, the high peak prices have the benefit of increasing the value of the PV production and reducing system payback periods.

Finally, demand charges are not an effective benefit for PV system owners because the charge is based on the maximum use during a billing period (usually a month). Even one cloud passing over a PV system during peak building load may cancel the effect of demand-charge savings. Consider, for example, a PV system that reduces a building's peak demand 29 days out of a 30day billing period; the customer will be charged for their peak demand, which occurred on the one day that the PV system had reduced function (perhaps due to cloud cover). Thus, the 29 days that the PV system did reduce the customer's peak load, becomes irrelevant. Only the highest use is billed. In reality, it may only take a 15-minute cloud cover for this effect to be true. 


\section{References}

Borenstein, S. (2007). "Electricity Rate Structures and the Economics of Solar PV: Could Mandatory Time-of-Use Rates Undermine California's Solar Photovoltaic Subsidies?" Center for the Study of Energy Markets paper CSEMWP-172. http://repositories.cdlib.org/ucei/csem/CSEMWP-172

Smeloff, E. (2005). "Quantifying the Benefits of Solar Power for California." White paper for the Vote Solar Initiative. Accessed at http://www.votesolar.org/tools_QuantifyingSolar'sBenefits.pdf

Wiser, R.; Mills, A.; Barbose, G.; Golove, W. (2007). "The Impact of Retail Rate Structures on the Economics of Commercial Photovoltaic Systems in California." Accessed March 2009 at http://repositories.cdlib.org/cgi/viewcontent.cgi?article=5510\&context=lbnl. 


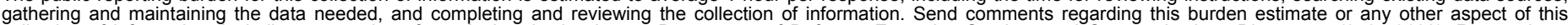

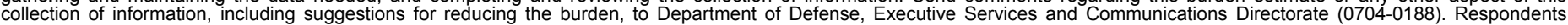

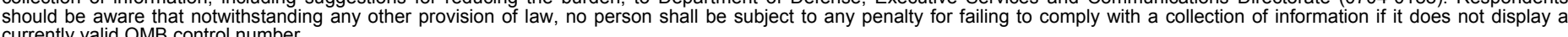

PLEASE DO NOT RETURN YOUR FORM TO THE ABOVE ORGANIZATION.

\section{REPORT DATE (DD-MM-YYYY) July 2009 \\ 2. REPORT TYPE \\ Technical Report}

4. TITLE AND SUBTITLE

Rate Analysis of Two Photovoltaic Systems in San Diego
3. DATES COVERED (From - To) 5a. CONTRACT NUMBER

DE-AC36-99-G010337

5b. GRANT NUMBER
6. AUTHOR(S)

E. Doris, S. Ong, and O. Van Geet 5d. PROJECT NUMBER

NREL/TP-6A2-43537

5e. TASK NUMBER

PVC7.92LA

5f. WORK UNIT NUMBER
7. PERFORMING ORGANIZATION NAME(S) AND ADDRESS(ES)

National Renewable Energy Laboratory

1617 Cole Blvd.

Golden, CO 80401-3393
8. PERFORMING ORGANIZATION REPORT NUMBER

NREL/TP-6A2-43537

9. SPONSORING/MONITORING AGENCY NAME(S) AND ADDRESS(ES)

10. SPONSOR/MONITOR'S ACRONYM(S) NREL

11. SPONSORING/MONITORING AGENCY REPORT NUMBER

12. DISTRIBUTION AVAILABILITY STATEMENT

National Technical Information Service

U.S. Department of Commerce

5285 Port Royal Road

Springfield, VA 22161

\section{SUPPLEMENTARY NOTES}

\section{ABSTRACT (Maximum 200 Words)}

Analysts have found increasing evidence that rate structure has impacts on the economics of solar systems. This paper uses 2007 15-minute interval photovoltaic (PV) system and load data from two San Diego City water treatment facilities to illustrate impacts of different rate designs. The comparison is based on rates available in San Diego at the time of data collection and include proportionately small to large demand charges (relative to volumetric consumption), and varying on- and off- peak times. Findings are twofold for these large commercial systems: 1) transferring costs into demand charges does not result in savings and 2) changes in peak times do not result in a major cost difference during the course of a year. While lessons learned and discussion on rate components are based on the findings, the applicability is limited to buildings with similar systems, environments, rate options, and loads.

\section{SUBJECT TERMS}

NREL; renewable energy; RE; California; San Diego; City of San Diego; Elizabeth Doris; Sean Ong; Otto Van Geet; solar photovoltaics; solar; PV; building energy; demand charges; water treatment facilities; peak load; rate options

\begin{tabular}{|c|c|c|c|c|}
\hline \multicolumn{3}{|c|}{ 16. SECURITY CLASSIFICATION OF: } & \multirow{2}{*}{$\begin{array}{l}\text { 17. LIMITATION } \\
\text { OF ABSTRACT } \\
\text { UL }\end{array}$} & \multirow{2}{*}{$\begin{array}{l}\text { 18. NUMBER } \\
\text { OF PAGES }\end{array}$} \\
\hline $\begin{array}{l}\text { a. REPORT } \\
\text { Unclassified }\end{array}$ & $\begin{array}{l}\text { b. ABSTRACT } \\
\text { Unclassified }\end{array}$ & $\begin{array}{l}\text { c. THIS PAGE } \\
\text { Unclassified }\end{array}$ & & \\
\hline
\end{tabular}

19b. TELEPHONE NUMBER (Include area code) 